\title{
SOLUSI PROBLEM PENGHAPUSAN BUNGA DENGAN PENDEKATAN PRODUK BAI' BITSAMAN ĀJIL DALAM UPAYA MEWUJUDKAN LEMBAGA KEUANGAN LĀ-RIBA (Studi Kasus di BMT Damar dan BMT-KJKS IAIN Walisongo Semarang)
}

\author{
Siti Mujibatun ${ }^{1}$
}

\begin{abstract}
Mudhärabah practices as an icon rather than LKS (Sharia Financial Institution) is still raise unresolved polemic associated with akunting system and balance, especially in the domain of financing, so that the stigma of people who think that the operating system is the same as the system of financial calculating interest only the different's name has been continues. When examined in detail, there are other products that legitimized the contract either by the arguments Syara agreed by the majority of scholars and schools of jurisprudence, namely the contract of Ba $i$ Bitsaman Ajil (BBA) or purchase by way of pay gradually.

This article concludes; First, offers a BBA in finance BMT Damar and BMT-KJKS IAIN W alisongo experiencing significant growth, in addition to a simple transaction models are not complex, almost the akunting system likes fixed rate (fixed rate) so that customers become more familiar because the system is not much different from the credit money. Second, $B B A$ financing acounting system can be separated from other products offered by BMT and not to be come one system with muräbahah financing. Third, although the BBA acounting system similar to the system of interest and somewhat complicated because managers have the purchase to be come representer for wakälah contract to goods of customers, but offers and akunting $B B A$ financing is more flexible and is not affected by rising interest rates as the often occurs in LKK( Conventional Financial Institutional)
\end{abstract}

Keyword: Solution, Interest Elimination, Products of $B B A$.

\section{Pendahuluan}

Karakteristik Lembaga Keuangan Syariah sebagai salah satu sistem ekonomi alternatif abad 21 dengan mengedepankan prinsip bisnis keuangan tanpa bunga (lä-riba), namun hingga kini belum mampu menghindari sistem

\footnotetext{
${ }^{1}$ Dosen Fakultas Ekonomi dan Bisnis Islam, UIN Walisongo Semarang
} 
bunga. Bahkan beberapa hasil penelitian mahasiswa S.1 jurusan Ekonomi Islam dan juga Muamalah Fakultas Syariah dan Ekonomi Islam sejak tahun 2006 sampai dengan tahun 2013 menyimpulkan bahwa sistem akunting dan neraca yang dipakai dalam manajemen bisnis keuangan syariah secara signifikan masih sama dengan sistem yang berlaku di Lembaga Keuangan Konvensional. ${ }^{2}$

Isu yang berkembang hingga kini menyatakan bahwa sistem penghitungan bagi hasil di Lembaga Keuangan Syariah (LKS) tidak berbeda dengan sistem yang berlaku di Lembaga Keuangan Konvensional (LKK), sebagaimana dikemukakan oleh para pakar keuangan Islam dari berbagai negara, seperti Syed Nawab Hedar Naqvi, pakar ekonomi Islam dari Pakistan, M. Umer Chapra dari Maroko, Munzer Kahf, W.M. Khan dari Islamabad.

Demikian pula di Indonesia misalnya Thoha Hasan, pebisnis muslim terkenal di Jawa Tengah sekaligus sebagai Presiden Organisasi Masyarakat Ekonomi Syariah (MES) Indonesia menyatakan bahwa praktik Lembaga Keuangan Syariah masih belum bisa menerapkan prinsip mudhärabah, karena sebagai alternatif produk tanpa bunga mudhärabah secara signifikan belum bisa diterapkan di Lembaga Keuangan Syariah (LKS). Di sisi lain sistem akunting dan neraca yang dipakai masih belum dapat menggeser sistem akunting dan neraca yang berlaku pada sistem bunga.

Menurut $\mathrm{Naqvi}^{3}$, bahwa ketentuan ekonomi Islam yang melarang riba, akan berhadapan dengan sistem bunga dalam pengertian ekonomi modern yang sulit dihindari. Pada sisi lain, ketika tingkat suku bunga dihapuskan (dalam posisi nol \%), belum dapat dianggap sebagai solusi karena tingkat bunga nol \% bisa terjadi kapan saja baik dalam ekonomi Islam maupun pada ekonomi non-Islam, sehingga tingkat bunga nol \% tidak bisa memadai terhadap keberadaan ekonomi Islam.

\footnotetext{
2 Data diakses dari arsip judul skripsi mahasiswa jurusan Ekonomi Islam dan jurusan Muamalah Fakultas Syari'ah IAIN Walisongo tahun 2006-2013.

${ }^{3}$ Syed Nawab Heidar Naqvi, Islam, Economics, and Society, terj. M. Syaeful Anam \& Muhammad Ufuqul Mubin dengan judul "Menggagas Ekonomi Islam", Yogyakarta: Pustaka Pelajar, 2003, hlm. $160-162$.
} 
Lebih lanjut dinyatakan oleh $\mathrm{Naqvi}^{4}$ bahwa reformasi ekonomi Islam bukan sekedar penggantian sistem bunga dengan elemen misalnya mudhärabah, salam, muräbahah dan lainnya, tetapi solusi yang lebih substantif adalah dengan konsep bagaimana instrumen finansial dapat memenuhi harapan bagi investor yang menolak risiko terutama mereka yang memperoleh bagi hasil rendah. Sehingga penggantian bunga dengan laba bukan merupakan refleksi reformasi keuangan Islam, karena hal itu sama saja dengan menggantikan kapitalisme berbasis bunga dengan kapitalisme berbasis laba. Bahkan dengan sistem pengaturan pengganti bunga, tidak boleh mendepak investor kecil yang menolak resiko, sehingga solusi penghapusan bunga dalam lembaga keuangan Islam harus non-trivial (tidak boleh secara asal-asalan; abal-abal).

Sulitnya menghindari sistem bunga dalam akunting bagi hasil serta terjadinya in-efisiensi manajemen, dengan mengedepankan jargon "yang penting berkah", bertentangan dengan rasionalitas bisnis dan sistem akunting dalam ekonomi modern.

Menurut kajian fiqh muamalah, terdapat bentuk transaksi yang dapat menghindarkan bunga yaitu BBA (Ba i Bitsaman Ajì), oleh para ulama mazhab fikih dan juga fatwa DSN-MUI diperbolehkan berdasarkan dalil normatif (hadis) dari Imam Ibn Majah, "Tiga hal yang di dalamnya terdapat berah; jual beli dengan bayar tangguh (BBA), muqāradhah (mudhārabah), dan campuran gandum dengan jelai untuk dikonsumsi orang-orang rumah bukan untuk dijual (HR. Ibn Majah CD nomor 2280) ${ }^{5}$.

Transaksi BBA (Bai` Bitsaman Ajji) dalam hadis tersebut memberi peluang signifikan dalam rangka mencari solusi problem penghapusan sistem bunga yang terjadi pada praktik bisnis di Lembaga Keuangan Syariah (LKS) tanpa harus melakukan rekayasa atau hilah, sehingga dengan transaksi BBA penghapusan sistem bunga dapat dihindari serta stigma masyarakat yang menganggap bahwa praktik LKS sekedar beda nama dengan LKK tidak terjadi lagi. Meskipun secara substansi praktik penghitungan dalam jual beli tangguh dengan sistem bunga tidak terdapat perbedaan secara signifikan. Bisa jadi

\footnotetext{
${ }^{4}$ Ibid., hlm. 169.

${ }^{5}$ Ibn Majah, Sunan Ibn Mäjah, (Mausū'ab al-Hadìts al-Syarif, edisi II, Tahun 1997), CD-ROM hadis no. 2280 .
} 
karena isu yang dikembangkan oleh para pakar ekonomi syariah adalah penghapusan bunga yang diinterpretasikan sebagai riba. Jika demikian, untuk menghindari bunga, solusi yang diterapkan dalam produk perbankan syariah atau pada unit usaha syariah yang lain pun bisa menggunakan pendekatan produk BBA dan atau muräbahah yang secara normatif kedua jenis akad tersebut memperoleh legalitas syariah (al-Qur'an dan hadis).

Konsep BBA secara sederhana dapat diilustrasikan sebagai berikut. Si A membeli motor vario seharga 20 juta rupiah, dengan sistem pembayaran angsuran selama waktu tertentu (20 bulan) dengan angsuran per bulan 1 juta rupiah berdasarkan kesepakatan antara pembeli dengan penjual. Meskipun harga vario pada saat angsuran bulan ke-5 atau ke-10 mengalami kenaikan, penjual tidak diperbolehkan meminta tambahan angsuran dengan aalasan sebagai penyesuaian harga vario yang mengalami kenaikan. Hal ini sama dengan sistem pinjam uang yang terjadi di LKK, jika BBA obyek utangpiutangnya barang (vario), sebagaimana praktik jual beli mindring (istilah Jawa), di LKK uang sebagai obyeknya .

Lain halnya akad muräbahah, penyebutan harga pokok barang sebagai rukun sahnya muräbahah (menurut pendapat mayoritas ulama mazhab, selain Ibn Hazm), menurut Ibn Hazm penyebutan harga pokok tidak menjadi rukun akad muräbahah. Sehingga antara akad BBA dengan muräbahah terdapat perbedaan signifikan baik dari sisi bentuk akad maupun dasar legalitas normatifnya. Pada akad BBA dasar legalitas normatif secara eksplisit disebutkan dalam hadis:

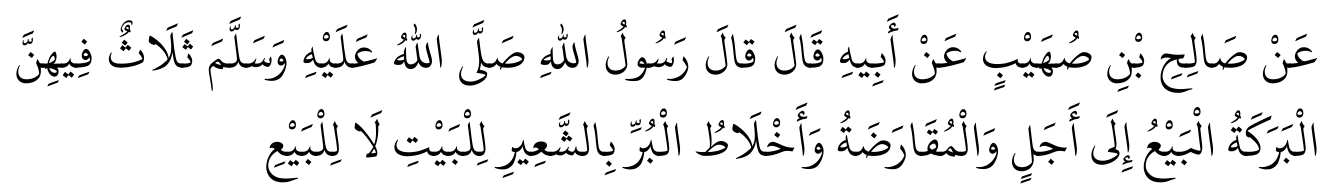

"Dari Shalih bin Shuhaib dari bapaknya ia berkata, Rasulullah saw bersabda: Tiga hal yang di dalamnya terdapat berkah; jual beli yang memberi tempo, peminjaman, dan campuran gandum dengan jelai untuk dikonsumsi orang-orang rumah bukan untuk dijual (HR. Ibnu Majah no file 2280).

serta berdasarkan pada keumumam dalil QS. al-Baqarah [2]:282 yang berbunyi: ......idz̃à tadāyantum bidainin ilā ajalin musamma......, maka pada akad muräbahah sebagaimana difatwakan oleh DSN dalam Himpunan Fatwa MUI 
tahun 2000 menggunakan ayat wa ahallāhu al-bai'a wa harrama al-ribā (QS. alBaqarah [2]:275) tidak secara eksplisit terdapat kata muräbahah, tetapi berdasarkan pemahaman makna bahwa muräbahah dalam fiqh termasuk salah satu dari berbagai bentuk akad yang dibolehkan syara. ${ }^{6}$ Demikian juga jika dilihat dalam hadis legalitas normatif muräbahah berdasarkan pada pernyataan Imam Malik dan kebiasaan masyarakat Madinah dan bukan langsung justifikasi dari Nabi saw. Dalam cuplikan kitab Muwaththa' dinyatakan;

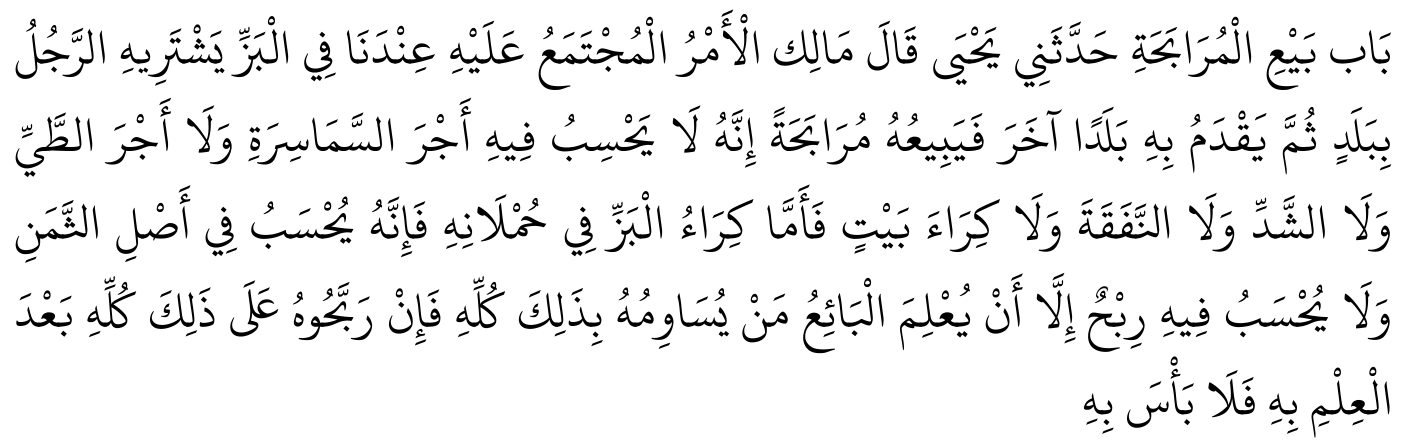

\section{Alasan penawaran produk BBA di BMT-KJKS Damar Dan IAIN Walisongo}

Pengelola LKS (BMT-KJKS Damar dan IAIN Walisongo) senantiasa mengusung ikon "bagi hasil" (profit and loss sharing), untuk menghindari riba (bunga) tanpa menjelaskan sistem akunting dan penghitungan bagi hasil yang diterapkannya, bahkan penggunaan sistem akuntingnya masih belum konsisten dengan prinsip yang difatwakan oleh DSN MUI, agaknya para praktisi kurang merespon terhadap isu tersebut, yang penting LKS bisa berjalan serta diminati oleh stakeholder (penyimpan dan pemutar modal).

Adapun penawaran produk BBA di BMT Damar dan BMT-KJKS IAIN Walisongo dengan pertimbangan:

6 Imam al-Shan'ani dalam kitab Subul al-Salām menyebutkan bentuk-bentuk jual beli yang dibolehkan menurut syara yaitu: jual beli barang dengan uang (bai mutlaq), barang dengan barang (barter- muqāyadhah), uang dengan uang (sharf), utang dengan uang (salam), barang dengan harga yang sama dan tidak mengambil laba (musawwamah), barang dengan harga tambahan dari harga pokok (muräbahab), harga barang lebih tinggi dari harga jual (muwadha'ah) lawan dari muräbahah dan ba'i tauliyah( jual beli barang secara harga tunai). Lihat al-Shan'ani, Subul al-Saläm, juz 3, Singapura: Mathba'ah al- Nasyr wa al-Tawz $\overrightarrow{1}, 1960$, hlm. 1. 
Solusi Problem Penghapusan Bunga ...

a. Minat masyarakat dalam memanfaatkan LKS terus meningkat dari tahun ke tahun.

b. BMT sebagai salah satu bentuk LKS telah dekat dan familiar di tengahtengah komunitas masyarakat terutama pebisnis dalam skala mikro kecil tidak sebagaimana bank.

c. Selain karena pertimbangan emosi keagamaan, sebagai lembaga keuangan, BMT bisa menyesuaikan dengan kebutuhan dan kepentingan masyarakat dalam mencari pinjaman dana guna memenuhi hajat hidup mereka. ${ }^{7}$

d. BMT merupakan bentuk lembaga bisnis keuangan dan bukan bisnis barang. Oleh karenanya, transaksi yang digunakan selalu menggunakan dua prinsip, yaitu prinsip akad wakälah dan prinsip kepercayaan, dimana pengelola BMT mewakilkan sekaligus mempercayakan kepada nasabah pembiayaan untuk membeli barang yang dikehendakinya, sehingga perbedaan antara LKK dengan LKS salah satunya yaitu perbedaan dalam penyebutan nama akad, karena menurut teori ekonomi Islam bahwa berbedanya jenis akad akan berakibat terjadinya hukum yang berbeda-beda pula.

\section{Sistem Akunting dalam produk BBA (Bai' Bitsaman Ājill)}

Cara penghitungan (sistem akunting dan neraca) yang dipakai oleh LKS termasuk BMT Damar dan BMT-KJKS IAIN Walisongo menggunakan sistem baku dan terstandar laporan keuangan yaang telah memperoleh legalitas dari Auditor Akuntan Publik.

Contoh sistem akunting produk BBA di BMT-KJKS yang berlaku di BMT-KJKS IAIN Walisongo:

\begin{tabular}{|l|l|l|c|c|}
\hline No & \multicolumn{1}{|c|}{$\begin{array}{c}\text { Tanggal } \\
\text { Angsuran }\end{array}$} & $\begin{array}{c}\text { Tanggal } \\
\text { Pembayaran }\end{array}$ & Out Standing & Total Angsuran \\
\hline & & & 12.491 .667 & \\
\hline 1. & 6 Juli 2007 & 4 Juli 2007 & 11.875 .000 & 616.667 \\
\hline 2. & 6 Agustus 2007 & 4 Agustus 2007 & 11.226 .667 & 608.333 \\
\hline
\end{tabular}

7 Wawancara dengan marketing BMT IAIN Walisongo, 20 Juli 2014 di kantor BMT IAIN Walisongo Jl. Mijen, dan Kepala Cabang Marketing BMT Damar, 20 Agustus 2014, di Kantor BMT Damar Ngaliyan. 
Siti Mujibatun

\begin{tabular}{|l|l|l|c|c|}
\hline 3. & 6 September 2007 & 6 September 2007 & 10.666 .667 & 600.000 \\
\hline 4. & 6 Oktober 2007 & 6 Oktober 2007 & 10.075 .000 & 591.667 \\
\hline 5. & 6 Nopember 2007 & 6 Nopember 2007 & 9.491 .667 & 583.333 \\
\hline 6. & 6 Desember 2007 & 6 Desember 2007 & 8.916 .667 & 575.000 \\
\hline 7. & 6 Januari 2008 & 6 Januari 2008 & 8.350 .000 & 566.667 \\
\hline 8. & 6 Pebruari 2008 & 6 Pebruari 2008 & 7.791 .667 & 558.333 \\
\hline 9. & 6 Maret 2008 & 6 Maret 2008 & 7.241 .667 & 550.000 \\
\hline 10. & 6 April 2008 & 6 April 2008 & 6.700 .000 & 541.667 \\
\hline 11. & 6 Mei 2008 & 6 Mei 2008 & 6.166 .667 & 533.333 \\
\hline 12. & 6 Juni 2008 & 6 Juni 2008 & 5.641 .667 & 525.000 \\
\hline 13. & 6 Juli 2008 & 6 Juli 2008 & 5.125 .000 & 516.667 \\
\hline 14. & 6 Agustus 2008 & 6 Agustus 2008 & 4.616 .667 & 508.333 \\
\hline 15. & 6 September 2008 & 6 September 2008 & 4.116 .667 & 500.000 \\
\hline 16. & 6 Oktober 2008 & 6 Oktober 2008 & 3.625 .000 & 491.667 \\
\hline 17. & 6 Nopember 2008 & 6 Nopember 2008 & 3.141 .667 & 483.333 \\
\hline 18. & 6 Desember 2008 & 6 Desember 2008 & 2.666 .667 & 475.000 \\
\hline 19. & 6 Januari 2009 & 6 Januari 2009 & 2.200 .000 & 466.667 \\
\hline 20. & 6 Pebruari 2009 & 6 Pebruari 2009 & 1.741 .667 & 458.333 \\
\hline 21. & 6 Maret 2009 & 6 Maret 2009 & 1.291 .667 & 450.000 \\
\hline 22. & 6 April 2009 & 6 April 2009 & 850.000 & 441.667 \\
\hline 23. & 6 Mei 2009 & 6 Mei 2009 & 416.667 & 433.333 \\
\hline 24. & 6 Juni 2009 & & & 425.000 \\
\hline & & & 24 bulan & 14.931 .000 \\
\hline
\end{tabular}

Penjelasan:

Berdasarkan penghitungan BBA tabel di atas menyatakan bahwa pembiayaan sebesar Rp. 10.000.000 (sepuluh juta rupiah) dengan sistem angsur selama 24 bulan (2 tahun), maka jumlah pengembaliannya menjadi sebesar Rp. 14.931 .000 (empat belas juta sembilan ratus tiga puluh satu ribu rupiah), 
Solusi Problem Penghapusan Bunga ...

sehingga BMT KJKS IAIN Walisongo mengambil keuntungan sebesar Rp. 14.931.000 - Rp. $10.000 .000=$ Rp. 4.931.000.

Jika dibandingkan dengan sistem akunting dan neraca pinjaman di LKK (Lembaga Keuangan Konvensional) akan nampak berbeda, berikut contoh penghitungan pada Bank Mandiri Cabang Semarang.

ANGSURAN PER BULAN PINJAMAN DI LKK ${ }^{8}$

\begin{tabular}{|c|c|c|}
\hline $\begin{array}{c}\text { LIMIT KREDIT } \\
(\mathrm{RP})\end{array}$ & $\begin{array}{c}\text { JANGKA WAKTU } \\
\text { (12 Bulan/1 Tahun) }\end{array}$ & $\begin{array}{c}\text { JANGKA WAKTU } \\
\text { (24 Bulan/2 Tahun) }\end{array}$ \\
\hline 10.000 .000 & 986.444 .66 & 493.222 .33 \\
\hline 25.000 .000 & 2.277 .154 & 1.233 .056 \\
\hline 30.000 .000 & 2.732 .585 & 1.065 .853 \\
\hline 35.000 .000 & 3.188 .015 & 1.726 .278 \\
\hline 40.000 .000 & 3.643 .446 & 1.972 .889 \\
\hline dan seterusnya & Menyesuaikan & Menyesuaikan \\
\hline
\end{tabular}

Tabel angsuran versi LKK dapat dipahami bahwa pinjaman sebesar Rp. 10.000.000 dalam jangka waktu angsuran selama 24 bulan (2 tahun) flat (angsuran tetap) sebesar: Rp. 493.222.33 x $24=$ Rp. 11.847.336, sehingga dari pinjaman sebesar Rp. 10.000.000, LKK mengambil bunga Rp. 11. 847.336 Rp. $10.000 .000=$ Rp. 1.847.336.

Berdasarkan perhitungan sistem bunga bisa dilihat bahwa sistem akunting dan neraca LKS dalam mengambil keuntungan lebih besar daripada LKK dengan perbandingan neraca bagi hasil BMT 20:80, sedangkan LKK dengan bunga $16.75 \%$ per tahun. ${ }^{9}$

\footnotetext{
${ }^{8}$ Perhitungan angsuran per bulan disesuaikan dengan besaran bunga yang ditetapkan oleh bank yaitu sebesar 16,75\% per tahun. Brosur tabel angsuran Multiguna Mandiri Cabang Pemuda Semarang.

9 Data diambil dari tabel angsuran BMT-KJKS IAIN Walisongo dan Bank Mandiri Cabang Pemuda Semarang yang telah diolah.
} 
Siti Mujibatun

\section{Keunggulan dan Kelemahan Sistem Akunting pada Produk BBA (Bai' Bitsaman Ājil)}

Keunggulan dan kelemahan sistem akunting dan neraca BBA (LKS) dan LKK

\begin{tabular}{|c|c|}
\hline \multicolumn{2}{|c|}{ Sistem Akunting dan Neraca BBA } \\
\hline Keunggulan & Kelemahan \\
\hline $\begin{array}{l}\text { 1. Sistem akunting dan neraca BBA } \\
\text { lebih fleksibel }\end{array}$ & $\begin{array}{l}\text { 1. Sistem akunting BBA dari } \\
\text { perspektif manajemen tidak efisien } \\
\text { (in-efisiensi) karena terlalu jlimet }\end{array}$ \\
\hline $\begin{array}{l}\text { 2. Angsuran disesuaikan pada } \\
\text { permulaan akad sekalipun harga } \\
\text { barang pembiayaan selalu naik dari } \\
\text { waktu ke waktu }\end{array}$ & $\begin{array}{l}\text { 2. Kurang praktis jika dibandingkan } \\
\text { dengan sistem bunga }\end{array}$ \\
\hline $\begin{array}{l}\text { 3. Jika angsuran dilakukan secara } \\
\text { menurun, akan kelihatan lebih } \\
\text { meringankan nasabah }\end{array}$ & $\begin{array}{l}\text { 3. Sifat kehati-hatian dalam } \\
\text { menghindari bunga, ternyata tidak } \\
\text { berpengaruh signifikan terhadap } \\
\text { tingkat pengambilan keuntungan }\end{array}$ \\
\hline $\begin{array}{l}\text { 4. Dalam perspektif ideologi, } \\
\text { meskipun beban angsuran lebih } \\
\text { tinggi dari sistem bunga, nasabah } \\
\text { BBA tetap lebih nyaman }\end{array}$ & $\begin{array}{l}\text { 4. Jika pengambilan keuntungan } \\
\text { pembiayaan BBA lebih tinggi } \\
\text { daripada sistem bunga, akan } \\
\text { berdampak pula terhadap beban } \\
\text { tinggi bagi nasabah (peminjam) } \\
\text { pembiayaan BBA. }\end{array}$ \\
\hline
\end{tabular}

\section{Solusi Problem Penghitungan Pembiayaan BBA}

Pada prinsipnya sistem akad yang berlaku di LKS selalu mengacu ke berbagai pendapat para tokoh atau pendiri mazhab fiqh klasik (terutama mazhab empat yaitu; Hanafi, Maliki, Syafi'i dan Hambali) yang dianggap masyhur dan diikuti oleh para ahli fikih dari generasi ke generasi dan juga mayoritas umat Islam hingga sekarang.

Sebagaimana dinyatakan oleh Ibn Qayyim al-Jauziyah bahwa pada prinsipnya akad menurut syariah selain "unsur kerelaan" juga harus 
mengedepankan prinsip atau kaedah al-'adl huwa asās al-'aqd ${ }^{10}$ (Keadilan adalah prinsip dasar daripada akad). Untuk itu, maka praktik pembiayaan BBA yang berlaku di LKS bisa menggunakan ijtihad berdasarkan prinsip-prinsip yang dikemukakan oleh Ibn Qayyim serta diikuti oleh mayoritas ulama fikih klasik yaitu "unsur saling rela dan adil".

Dengan berpegang pada "unsur saling rela dan adil", maka sesungguhnya ijtihad para pakar ekonomi syariah dapat mempertimbangkan sistem akunting yang berlaku di LKK, kecuali satu yang dipertahankan yaitu pemakaian nama akad sebagai karakter bagi LKS karena pada prinsipnya istilah-istilah yang dipakai dalam sistem transaksi LKS mengacu kepada namanama akad yang bersumber dari al-Qur'an, hadis maupun hasil ijtihad para ulama dari masa ke masa hingga munculnya gerakan Lembaga Keuangan Syariah dengan sistem perbankan sebagai salah satu ikonnya. Sekalipun nama akadnya berbeda-beda, akan tetapi dalam waktu bersamaan berbagai jenis akad bisa berjalan berkelindan menjadi sebuah istilah yang biasa dipraktikkan dalam LKK atau akad-akad modern seperti; asuransi (kafälab), deposito (wadīab), wesel atau cek (biwālah) dan sejenisnya ${ }^{11}$. Kesemuanya itu merupakan lapangan ijtihad dalam rangka pengembangan teori-teori yang telah ada sejak pra atau masa-masa awal Islam bersamaan dengan berkembangnya ilmu dan peradaban umat manusia dari zaman batu ke zaman post modern bahkan pada era globalisasi saat ini dan mendatang.

Terbukanya pintu ijtihad bagi umat Islam terutama dalam bidang ekonomi/bisnis memberikan peluang bagi para pakar dan praktisi LKS untuk mengelaborasi sistem akunting yang telah ada (LKK) dengan penyesuaian sistem terhadap berbagai jenis akad yang diberlakukan, sehingga akan dijumpai unsur-unsur kesamaan antara akad menurut LKK dengan akad yang berlaku di LKS. Hal ini dapat dilihat pada sistem yang telah diterapkan oleh BTN (Bank Tabungan Negara) Syariah dalam penawaran produk KPR BTN IB (Kredit Kepemilikan Rumah Bank Tabungan Negara Islamic Bank) sebagaimana contoh berikut ini:

\footnotetext{
${ }^{10}$ Ibn Qayyim al-Jauziyah, I'lam al- Muwaqi'īn, juz II, Mesir: Maktabah al-Tijāriyah, 1987, hlm. 7.

${ }^{11}$ Sayid Sabiq, Fiqh al-Sunnah, Beirut: Dār al-Kitāb al-'Arabi, 1971, hlm. 169.
} 


\section{ANGSURAN PEMBIAYAAN SYARIAH KPR BTN IB}

\begin{tabular}{|c|c|c|c|c|c|c|c|c|}
\hline \multirow{2}{*}{$\begin{array}{l}\mathrm{N} \\
\mathrm{O}\end{array}$} & \multirow{2}{*}{$\begin{array}{c}\text { Plafond } \\
\text { (Rp) }\end{array}$} & \multicolumn{7}{|c|}{ Jangka Waktu (Bulan) } \\
\hline & & 24 & 48 & 72 & 96 & 120 & 144 & 168 \\
\hline 1. & 20.000 .000 & 952.000 & 535.000 & 673.000 & 535.000 & 452.000 & 398.000 & 363.000 \\
\hline 2. & 30.000 .000 & 1.188 .000 & 800.000 & 597.000 & 504.000 & 453.000 & 425.000 & 410.000 \\
\hline 3. & 50.000 .000 & 2.375 .000 & 899.000 & 795.000 & 640.000 & 600.000 & 507.000 & 482.000 \\
\hline 4. & 60.000 .000 & 2.849 .900 & 999.90 & 898.000 & 922.000 & 872.000 & 779.000 & 692.000 \\
\hline 5. & dst & & & & & & & \\
\hline
\end{tabular}

Penjelasan:

Tabel di atas merupakan tabel simulasi angsuran pembiayaan KPR BTN IB dengan sistem akunting dan neraca pembayaran angsuran secara tetap sampai dengan batas waktu maksimal 180 bulan atau 15 Tahun lamanya dan dijamin tidak akan ada perubahan (menjadi bertambah) karena bertambah lamanya waktu angsuran atau sampai lunas angsurannya. Bentuk atau sistem BBA yang demikian itulah sesungguhnya yang dimaksud oleh syariah (fikih), sehingga bagi LKS seharusnya ketika melakukan penawaran produk BBA tidak harus dengan menyebut bagi hasil, tetapi bisa langsung menyebutkan harga atau nilai harga jual barang dengan menentukan besaran keuntungan LKS dari pembiayaan barang yang dikehendaki nasabah kemudian menyetujui berapa kali (biasanya per bulan) angsuran tersebut dibayarkan kepada LKS.

Dengan begitu, maka praktik pembiayaan BBA tidak ambigu dengan akad mudhärabah (bagi-hasil) maupun muräbahah, karena antara BBA, mudhärabah dan murābahah masing-masing memiliki karakter bentuk akad yang berbeda satu dengan lainnya serta sistem akunting yang terpisah.

Misalnya, pada mudhārabah masih mengandung ambigu yaitu ketika sistem akunting diterapkan akan bertentangan dengan asas/prinsip mudhārabah, karena dalam mudhārabah, pemutar dana tidak boleh dibebani membayar/ mengembalikan modal pokoknya secara angsur kepada shähib al-mäl (pemilik dana). Demikian pula pada muräbahah secara praksis berbeda dengan BBA, jika BBA, nasabah langsung membayar angsuran setiap bulan sesuai dengan jumlah harga barang yang harus diangsur. Lain halnya dengan murābahah, sistem 
akunting dan neraca pembayaran muräbahab bisa dilakukan oleh nasabah hanya dengan membayarkan jumlah margin keuntungannya saja tanpa disertai angsuran harga pokok barang.

Contoh akunting di atas dapat dibedakan antara BBA dengan muräbahah, jika angsuran pembiayaan BBA dilakukan bersama antara keuntungan LKS dengan pinjaman pokoknya dibagi dengan lama waktu angsur, serta tidak akan terjadi penambahan angsuran sampai selesainya batas akhir (jatuh tempo) akad. Bedanya dengan muräbahah, pembayaran angsuran pada muräbahah dilakukan hanya terhadap margin keuntungannya, sedangkan harga pokok barang dibayarkan pada akhir jatuh tempo pembayaran angsuran marginnya.

Demikian penjelasan terhadap perbedaan sistem akunting pembiayaan BBA dan muräbahah yang masing-masing akad tersebut memiliki karakter yang berbeda, dan khusus untuk sistem akunting pembiayaan BBA bisa persis (sama dengan) sistem akunting kredit uang yang berlaku di LKK dengan mengabaikan kenaikan tingkat suku bunga yang berlaku.

\section{Kesimpulan}

Sulitnya menghilangkan bunga di Lembaga Keuangan Syariah (LKS) karena beberapa faktor yaitu: kurang pahamnya pengelola LKS terhadap jenisjenis produk yang ditawarkan, sehingga setiap melakukan transaksi selalu memakai istilah bagi hasil, padahal sesungguhnya terdapat berbedaan yang signifikan antara berbagai jenis akad, sistem akunting dan neraca pembiayaan di LKS sama dengan sistem yang berlaku di LKK, yang membedakan antara kedua lembaga tersebut terletak pada penyebutan nama akad dan juga model ijab qabulnya.

Pembiayaan BBA memiliki keunggulan antara lain; sistem akunting dan neraca BBA lebih fleksibel, angsuran disesuaikan pada permulaan akad (tetap), sekalipun harga barang pembiayaan selalu naik dari waktu ke waktu, jika angsuran dilakukan secara menurun, akan kelihatan lebih meringankan nasabah, dalam perspektif ideologi, meskipun beban angsuran lebih tinggi dari sistem bunga, nasabah BBA tetap lebih nyaman. 
Sedangkan kelemahan pembiayaan BBA antara lain; sistem akuntingnya tidak efisien (in-efisiensi) karena terlalu rumit, kurang praktis jika dibandingkan dengan sistem penghitungan bunga, sifat kehati-hatian dalam menerapkan manajemen akunting, ternyata tidak berpengaruh signifikan terhadap tingkat pengambilan keuntungan.

Untuk mengatasi problem penghapusan bunga pada Lembaga Keuangan Syariah (LKS) dapat menggunakan produk pembiayaan BBA sepanjang jumlah angsuran yang dibayarkan oleh nasabah tidak berubah sejak disepakati pada awal akad sampai akhir jatuh tempo pembayaran.

Dari penelitian ini, ada sejumlah rekomendasi yang penulis sampaikan. Pertama, munculnya stigma negatif terhadap sistem akunting produk LKS sama dengan LKK terutama pada pembiayaan mudhärabah dan muräbahah perlu diimbangi dengan informasi tentang produk BBA yang telah memperoleh justifikasi baik dari sumber hadis, pendekatan qiyas maupun dukungan dari mayoritas tokoh mazhab fikih, sehingga dukungan dari DSN (Dewan Syariah Nasional) melalui produk fatwanya sangat penting dalam rangka meng-clier-kan stigma negatif tersebut.

Kedua, para pakar maupun para praktisi LKS perlu diberi pemahaman tentang perbedaan prinsip antara BBA dengan murābahah dan juga mudhärabah, masing-masing ketiga akad tersebut memiliki karakter yang berbeda baik secara teori maupun secara praktik di lapangan, sehingga tidak menjadikan informasi tumpang tindih terhadap produk pembiayaan yang dikelolanya serta tidak menjadikan para stakeholder LKS semakin bingung atau semakin tidak paham tentang jenis-jenis pembiayaan yang ditawarkan LKS

Ketiga, penguatan produk pembiayaan BBA terus dilakukan, maka ke depan perkembangan pengelolaan dana, aset maupun pangsa pasar LKS setidaknya akan dapat mengimbangi secara signifikan terhadap pertumbuhan yang dikelola oleh LKK.

Keempat, penentuan keuntungan pembiayaan BBA yang dilakukan oleh pengelola LKS masih perlu menyesuaikan naik turunnya suku bunga agar para stakeholder tidak merasa terbebani biaya terlalu tinggi, karena sistem akunting dan neraca LKS terutama pada domain perbankan dan BMT-KJKS masih mengikuti sistem akunting yang berlaku di LKK 
Solusi Problem Penghapusan Bunga ...

\section{DAFTAR PUSTAKA}

Jauziyah (al), Ibn Qayyim, I'lam al- Muwaqqi'in, Mesir: Maktabah al-Tijāriyah, 1987.

Kumpulan Fatwa DSN-MUI Tahun 2000

Majah, Ibn, Sunan Ibn Majah, Mausū'ah al-Hadīts al-Syarīf, edisi II, tahun 1997, File CD-ROM Hadis No. 2280.

Naqvi, Syed Nawab Haedar, Islam, Economics, and Society, terj. M. Syaeful Anam \& Muhammad Ufuqul Mubin dengan judul "Menggagas Ekonomi Islam”, Yogyakarta: Pustaka Pelajar, 2003.

Sabiq, Sayid, Fiqh al-Sunnah., Beirut: Dār al-Kitāb al-'Arabi, 1971.

SOP BMT Damar dan BMT-KJKS IAIN Walisongo 